\title{
EVALUASI DAN PENGEMBANGAN JARINGAN IRIGASI RAWA PASANG SURUT TERHADAP POLA OPERASI PINTU AIR D.I.R PEMATANG LIMAU KABUPATEN SERUYAN
}

\author{
Hairin Noor ${ }^{1}$ Suhardjono ${ }^{2}$ Tri Budi Prayogo ${ }^{2}$ \\ ${ }^{1}$ Staf Dinas Pekerjaan Umum dan Penataan Ruang Kabupaten Seruyan \\ ${ }^{2}$ Dosen Jurusan Teknik Pengairan Fakultas Teknik Universitas Brawijaya \\ Email: hrnsda.99@gmail.com
}

\begin{abstract}
ABSTRAK: Kabupaten Seruyan Propinsi Kalimantan Tengah secara umum memiliki lahan dan air yang cukup tersedia. Daerah Irigasi Rawa (D.I.R) Pematang Limau dipengaruhi oleh muka air pasang surut yang terjadi pada Sungai Seruyan. Pada musim hujan, muka air meningkat akibat air pasang dan curah hujan. Sementara di musim kemarau lahan menjadi kering. Untuk itu perlu dilakukan pengaturan pola operasi pintu air. Untuk mengetahui profil aliran di saluran primer digunakan software HEC-RAS 5.0.1 pada kondisi kering. Simulasi dilakukan dengan: (1) simulasi debit air pasang tanpa pintu air, (2) simulasi pintu air (existing), (3) simulasi dengan merubah lebar pintu air saluran primer dari $1 \mathrm{~m}$ menjadi 1,5 m dan (4) merubah koefisien Manning dari 0,027 menjadi 0,018. Dari beberapa simulasi yang dibuat, simulasi kedua menunjukkan elevasi muka air tertinggi pada cross section 1-12, namun tidak mampu menggenangi lahan yang berada di kanan atau kiri cross section 10-12. Langkah penanganan selanjutnya dengan menutup pintu air pada saluran primer ketika puncak debit pasang. Berdasarkan hasil perhitungan, kedalaman genangan pada lahan sebesar $0,001 \mathrm{~m}$ atau $1 \mathrm{~mm}$ jika secara bersamaan, sedangkan jika dilakukan secara bergilir $0,015 \mathrm{~m}$ atau $1,5 \mathrm{~cm}$. Hasil perhitungan genangan yang terjadi akibat hujan $0,061 \mathrm{~m}$ atau 6,1 $\mathrm{cm}$, sedangkan hasil perhitungan di saat pasang dan bersamaan terjadinya hujan diperoleh $0,062 \mathrm{~m}$ atau $6,2 \mathrm{~cm}$. Alternatif terakhir untuk mengatasi kekeringan adalah dengan sistem pompanisasi. Hasil perhitungan dengan lama operasi pompa 10 jam/hari selama 6 hari, untuk kedalaman genangan (y) $5 \mathrm{~cm}$, maka kebutuhan unit pompa sebesar 12 buah.
\end{abstract}

Kata kunci: Pasang surut, irigasi, pintu air, rawa.

ABSTRACT. Seruyan District in Central Kalimantan generally has sufficient land and water. The Swamp Irrigation Area (S.I.A) in Pematang Limau is influenced by the tidal waters that occur in Seruyan river. In the rainy season, the water levels increase due to high tide and rainfall. While in dry season the land becomes dry. Therefore, it is necessary to adjust the operation pattern of the sluice gate. To find out waterflow profile of the primary channel,it's used sofware HEC-RAS 5.0.1 under dry conditions. The simulation is done in four conditions, such as: (1) simulation based on input of tidal water discharge without sluice gate, (2) simulation with existing sluice gate, (3) simulation by widening the main channel of sluice gate from 1 meter to 1.5 meters, and (4) change the Manning coefficient from 0.027 to 0.018 . From several simulations, the second simulation shown the highest water level elevation in the cross section 1-12, but is not able to inundate the land on the right and left cross section 10-12. The next step is closing the sluice gate at the tidal peak discharge. Based on the calculation the depth of inundation on the land of 0.001 meters or 1 millimeter if it is simultaneously, whereas in rotation 0.015 meters or 1.5 centimeters. The result of the calculation of inundation that occurred due to rain 0.061 meters or 6.1 centimeters, while at on the water tide and simultaneous occurrence of rain obtained 0.062 meters or 6.2 centimeter. The last alternative is with pumping system. The calculation results with the duration of pump operation 10 hours / day for 6 days, the depth of the inundation (y) 5 centimeters, then the needs of pump unit are 12 units.

Keywords: Tidal, irrigation, sluice gate, swamp. 


\section{Latar Belakang}

Secara umum lahan dan air untuk pertanian di Kabupaten Seruyan Propinsi Kalimantan Tengah cukup tersedia, tetapi potensi yang ada tersebut belum sepenuh-nya dimanfaatkan optimal. Dengan me-ningkatnya kebutuhan penduduk terhadap kebutuhan pangan menuntut pemerintah melakukan upaya intensifikasi dan eksten-sifikasi pertanian. Peta jaringan D.I.R Pe-matang Limau disajikan pada Gambar 1.

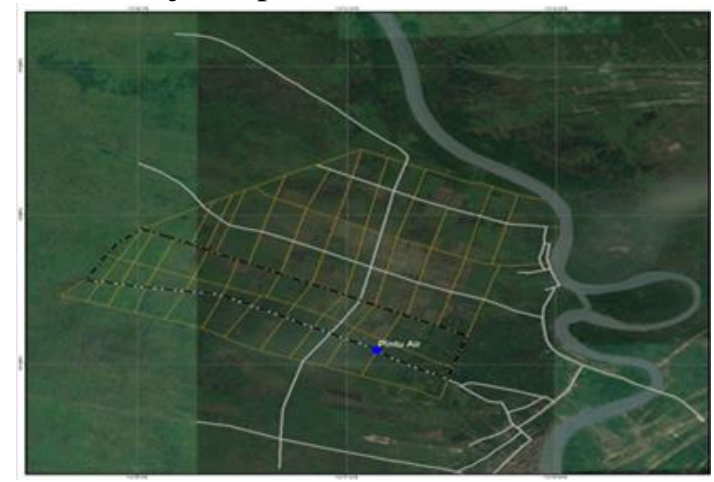

Gambar 1. Peta jaringan D.I.R Pematang Limau

\section{Identifikasi Masalah}

Teridentifikasi permasalahan yang ter-jadi pada D.I.R Pematang Limau adalah sebagai berikut:

1. Daerah Irigasi Rawa (D.I.R) Pematang Limau memiliki permasalahan ketika musim kemarau mengalami kekurang air dan ketika musim hujan mengalami kelebihan air.

2. Menurunnya fungsi saluran primer de-ngan panjang saluran $\pm 4,5$ kilometer, hal ini terjadi akibat tidak berfungsinya pintu air yang ada di saluran primer dan setiap saluran sekunder belum memiliki pintu air.

3. Pada kondisi existing lebar pintu air yang ada di saluran primer tidak maksimal, sehingga berpotensi meng-hambat debit air pasang masuk dan saluran primer bagian hulu (upstream) tidak sepenuhnya terisi.

\section{Rumusan Masalah}

Berdasarkan identifikasi masalah di atas dapat dirumuskan masalah penelitian ini, yaitu:

1. Sejauh mana pengaruh elevasi muka air di hulu saluran primer terhadap dimensi existing saluran primer dan pintu air ?

2. Bagaimana alternatif penanganan di saat terjadi kekurangan air atau terjadi kelebihan air sebagai akibat pengaruh fluktuasi muka air pasang surut pada saluran primer?
3. Bagaimana rekomendasi alternatif sis-tem saluran primer dan pintu air untuk mengatasi permasalahan yang terjadi di daerah studi?

\section{Batasan Masalah}

Batasan masalah pada studi ini dibuat agar tidak menyimpang dari pokok bahas-an, antara lain:

1. Pemodelan fluktuasi muka air pasang surut menggunakan bantuan software HEC-RAS versi 5.0.1.

2. Penelitian ini dilakukan untuk membanding tinggi evelevasi muka air pasang tanpa pintu air dan dengan ada pintu air, untuk mengetahui zona mana saja yang mengalami kekurangan air serta zona mana saja yang mengalami kelebihan air.

3. Penelitian ini tidak membahas masalah kualitas air ataupun sedimentasi yang terjadi pada saluran primer.

\section{Tujuan Penelitian}

Studi ini bertujuan untuk:

1. Melakukan analisa pengaruh elevasi muka air di hulu saluran primer terha-dap dimensi existing saluran primer dan pintu air.

2. Melakukan analisa dan alternatif penanganan di saat terjadi kekurangan air atau terjadi kelebihan air sebagai akibat pengaruh fluktuasi muka air pasang surut pada saluran primer.

3. Memberikan rekomendasi sistem salur-an primer dan pintu air untuk mengatasi permasalahan yang terjadi di daerah studi.

\section{TINJAUAN PUSTAKA}

Reklamasi rawa adalah upaya meningkatnya fungsi dan pemanfaatan rawa untuk kepentingan masyarakat luas. Reklamasi daerah rawa juga merupakan salah satu bentuk ekstensifikasi pertanian yang dila-kukan dengan membuka, memanfaatkan serta melestarikan rawa sebagai sumber daya alam bagi kesejahteraan kehidupan manusia.

Tujuan pengembangan lahan rawa melalui reklamasi (Suhardjono dkk., 2010) adalah:

1. Pengembangan produktifitas pangan khususnya beras.

2. Memperluas lahan persawahan yang su-dah semakin berkurang.

3. Menyediakan lahan pertanian dan meningkatkan pendapatan bagi para transmigran. 
4. Menunjang pengembangan wilayah produktif serta meningkatkan penghasilan petani.

5. Mendukung program ketahanan dan keamanan terutama di daerah pesisir serta perbatasan.

Konsep pengembangan lahan rawa dilakukan secara bertahap dalam rangka pengembangan sumber daya air di Indonesia dengan fungsi budidaya. Kriteria pengembangan lahan rawa sebagai kawas-an budidaya (Anonim, 2008) adalah:

1. Kawasan yang secara teknis dapat dimanfaatkan sebagai kawasan budidaya.

2. Kawasan yang dapat meningkatkan perkembangan pembangunan lintas sektor dan sub sektor kegiatan ekonomi seki-tarnya.

3. Kawasan yang apabila digunakan untuk budidaya akan meningkatkan pendapat-an nasional dan daerah.

4. Kawasan yang apabila digunakan untuk budidaya tidak mengganggu fungsi lin-dung dan pelestarian sumber daya alam.

Persamaan-persamaan yang diguna-kan dalam menyelesaikan studi ini, di-antaranya:

Debit limpasan permukaan menggunakan Metode Rasional dengan persamaan (Suhardjono. 2015: 104):

$$
Q=0,00278 . C . I . A
$$

dengan:

$\mathrm{Q}=$ debit limpasan rencana $\left(\mathrm{m}^{3} /\right.$ detik).

$\mathrm{C}=$ koefisien limpasan (tak berdimensi).

I = intensitas hujan pada durasi yang sama dengan waktu konsentrasi dan periode ulang hujan tertentu (mm/jam).

A = luas daerah pengaliran (hektar).

Koefisien limpasan (C) ditentukan dengan menggunakan Rumus Koefisien Limpasan Tertimbang atau $\mathrm{C}$ equivalent, dengan persamaan (Suripin. 2004: 81):

$$
C_{e q}=\frac{\sum_{i=1}^{n} C_{i} \cdot A_{i}}{\sum_{i=1}^{n} A_{i}}
$$

dengan:

$\mathrm{C}_{\mathrm{eq}}=$ koefisien limpasan ekivalen.

$\mathrm{C}_{\mathrm{i}}=$ koefisien limpasan sub-sub DAS/sub-sub DPS.
$\mathrm{A}_{\mathrm{i}}=$ luas masing-masing sub DAS/sub DPS.

Perhitungan intensitas curah hujan dengan Rumus Mononobe (Suripin, 2004: 67-68): sebagai berikut:

$$
I=\frac{R_{24}}{24} x\left(\frac{24}{t}\right)^{2 / 3}
$$

dengan:

I = intensitas hujan ( $\mathrm{mm} / \mathrm{jam})$

$\mathrm{t}=$ lamanya hujan (jam)

$\mathrm{R}_{24}=$ curah hujan maksimum harian ( $\mathrm{mm}$, selama 24 jam)

Persamaan energi digunakan sebagai dasar perhitungan, diberikan oleh per-samaan berikut ini (Chow, 1997: 243):

$h_{1}+\alpha_{1} \frac{U_{1}^{2}}{2 g}+z_{1}=h_{2}+\alpha_{2} \frac{U_{2}^{2}}{2 g}+z_{2}+h_{f}+h_{e}$

dengan:

$\mathrm{g}=$ percepatan gravitasi $(\mathrm{m} / \mathrm{dtk})$

$\mathrm{h}_{\mathrm{f}}=$ kehilangan tinggi akibat gesekan $(\mathrm{m})$

$\mathrm{h}_{\mathrm{e}}=$ kehilangan tinggi akibat perubahan penampang $(\mathrm{m})$

$\mathrm{U}=$ kecepatan rerata $(\mathrm{m} / \mathrm{dtk})$

$\alpha=$ koefisien distribusi kecepatan

$\mathrm{z}=$ ketinggian dari datum $(\mathrm{m})$

$\mathrm{h}=$ kedalaman $\operatorname{air}(\mathrm{m})$

Adapun contoh pintu air pada saluran disajikan pada Gambar 2 di bawah ini.

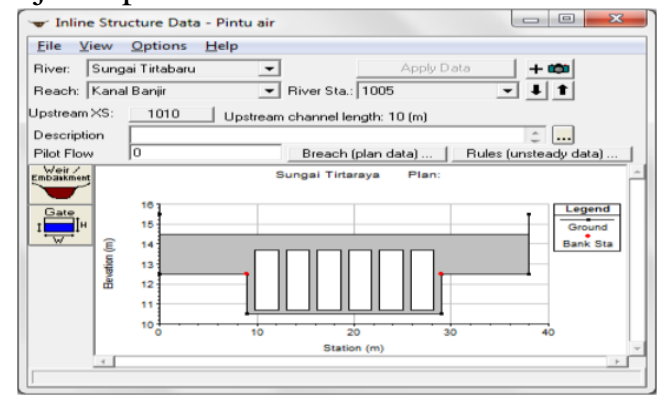

Gambar 2. Contoh pintu air pada saluran Sumber: Istiarto (2014: 7)

\section{BAHAN DAN METODE \\ Bahan}

Data yang diperlukan untuk mendu-kung penyelesain penelitian ini adalah:

1. Peta tata guna lahan

Peta untuk mengetahui tata guna lahan di lokasi studi DIR. Pematang Limau yang berada di kecamatan Seruyan Hilir, peta 
dimaksud diperoleh dari Citra Satelit Google Earth 2016, peta diperlukan untuk mengetahui nilai koefisien pengaliran di wilayah studi.

2. Data curah hujan

Data curah hujan harian maksimum didapat dari stasiun curah di sekitar wilayah studi, yaitu: Stasiun Kantor Dinas Pekerjaan Umum Kabupaten Seruyan dan Stasiun Kantor Pengamat Pengamat Pengairan Seruyan Hilir Timur. Data curah hujan yang tersedia mulai tahun $2005 \mathrm{~s} / \mathrm{d}$ 2016.

3. Data Topografi

Data topografi lahan diperlukan untuk melakukan perhitungan luasan daerah pengaliran yang berpengaruh terhadap debit rancangan, peta ini diperoleh dari Citra Satelit Google Earth2016 dengan bantuan ArcMap Versi 10.3.

4. Data sitem tata air

Sistem tata air digunakan sebagai dasar untuk membuat pemodelan, data terse-but terdiri dari:

- Data saluran irigasi (existing)

Pengukuran data penampang memanjang (long section) dan penam-pang melintang (cross section) di-lakukan.

- Data pintu air (existing)

Pengukuran dimensi pintu air untuk melakukan pemodelan hambatan debit air pasang terhadap tinggi elevasi muka air di bagian hulu (upstream) yang berpengaruh terha-dap kedalaman genangan pada lahan.

5. Data pasang surut

- Data fluktuasi pasang surut

Data pasang surut diperoleh dengan melakukan pengamatan selama 16 hari pada tahun 2017. Lokasi di saluran primer DAS Seruyan yang terletak $03^{\circ}$ 36'39' dan $112^{\circ} 55^{\prime} 50^{\prime}$ '.

- Data debit pasang

Data debit pasang digunakan untuk membuat pemodelan. Data ini diperoleh dengan melakukan pengukuran langsung di saluran primer DIR. Pematang Limau.

\section{Metode}

Berdasarkan data yang tersedia maka langkah selanjutnya untuk menyelesaikan kajian ini adalah sebagai berikut:

1. Menghitung curah hujan curah harian maksimum tahunan. Hal ini dilakukan untuk mendapatkan debit air akibat curah hujan di wilayah catchment area.

2. Melakukan uji konsistensi/kesesuaian data curah hujan dengan metode RAPS (Rescaled Adjusted Partial Sums).

3. Menghitung curah hujan dengan meto-de Normal, Log Normal, Gumbel dan Log Person tipe III.

4. Melakukan uji kesesuaian distribusi secara vertikal Chi Kuadrat dan Uji Kesesuaian distribusi secara horizontal Smirnov Kolmogorov.

5. Menghitung intensitas hujan dengan Mononobe

6. Menentukan koefisien pengaliran (C), yaitu: perbandingan antara jumlah air yang mengalir di suatu daerah akibat turunnya hujan dengan jumlah air hujan yang turun di daerah tersebut.

7. Menghitung luas daerah pengaliran saluran pada setiap saluran sekunder dengan menggunakan bantuan ArcMap Versi 10.3

8. Menghitung debit rancangan dengan metode Rasional.

9. Mengevaluasi kapasitas saluran sekun-der, pada saat musim hujan dengan curah hujan harian maksimum rerata.

10. Menghitung konstanta pasang surut metode Least Square dengan menggunakan bantuan aplikasi Pasut UGM.

11. Memodelkan profil memanjang (long section) saluran primer dengan bantuan HEC-RAS 5.01 kondisi pasang pada saat tidak terjadi hujan.

Adapun diagram alir penelitian disaji-kan pada Gambar 3 di bawah ini. 


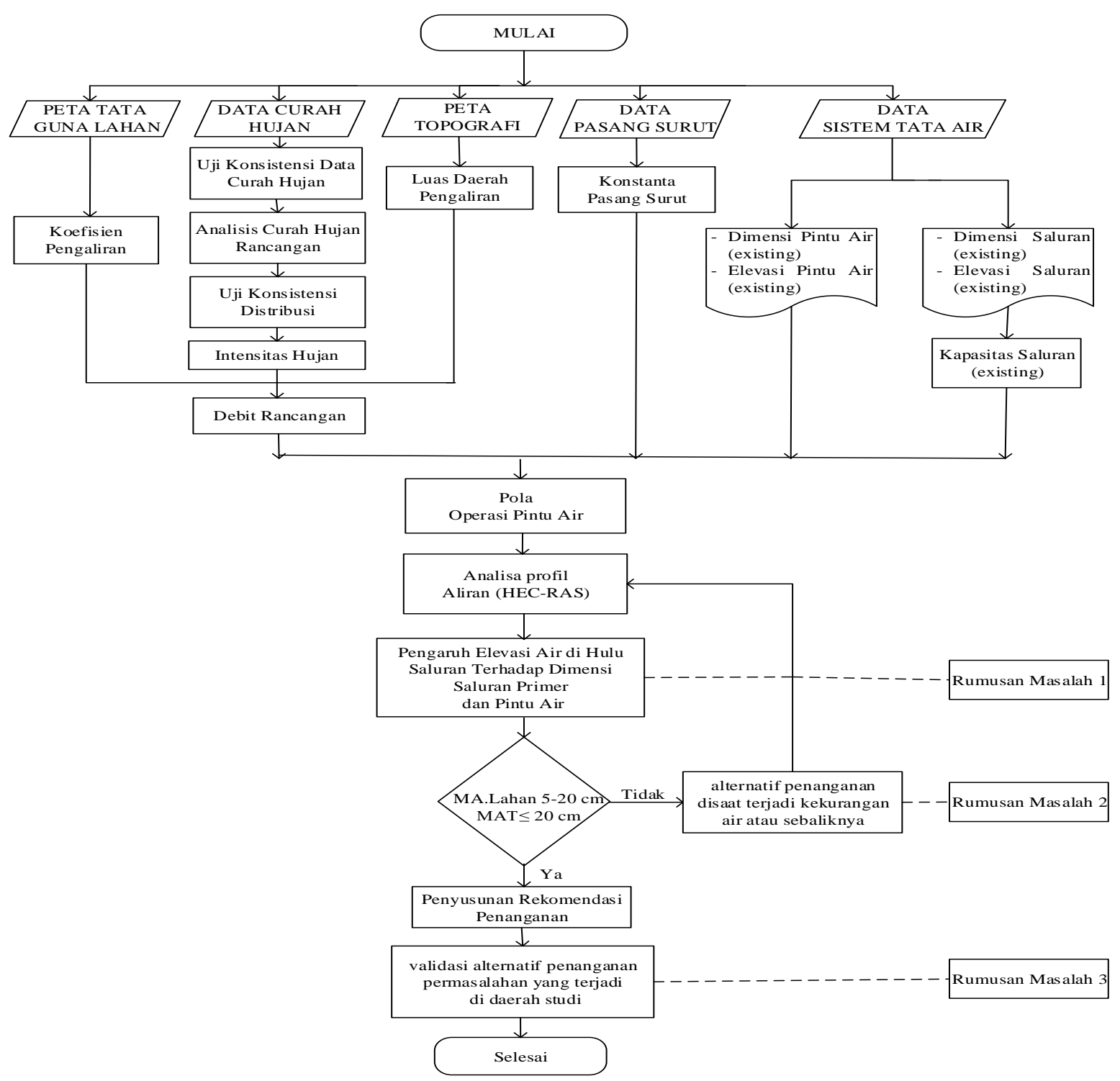

Gambar 3 Diagram Alir Penelitian

\section{HASIL DAN PEMBAHASAN}

Hasil

\section{Uji Konsistensi Data}

Uji Konsistensi menggunakan data dari stasiun CH. PUPR dan P2SHT I. Hasil Uji Konsistensi metode RAPS (Rescale Adjusted Partial Sums) pada kedua stasiun tersebut nilai $\mathrm{Q} /\left(\mathrm{n}^{0.5}\right)<\mathrm{Q} /\left(\mathrm{n}^{2}\right)$ artinya data hujan konsisten.

\section{Perhitungan Curah Hujan Rerata}

Perhitungan curah hujan daerah dari pengamatan di beberapa titik mengguna-kan rerata Aljabar. Adapun hasil perhitun-gan disajikan pada Tabel 1.
Tabel 1. Curah Hujan Harian Rerata

\begin{tabular}{|c|c|c|c|c|c|c|c|}
\hline No. & Tahun & Bulan & Tanggal & $\begin{array}{c}\text { Sta. } \\
\text { PUPR } \\
\text { (mm) }\end{array}$ & $\begin{array}{c}\text { Sta. } \\
\text { P2SHT } \\
(\mathrm{mm})\end{array}$ & $\begin{array}{l}\text { Rerata } \\
(\mathbf{m m})\end{array}$ & $\begin{array}{l}\text { CH. } \\
\text { Maks }\end{array}$ \\
\hline \multirow[t]{2}{*}{1} & 2007 & 1 & 24 & 132 & 47 & 90 & \multirow{2}{*}{146} \\
\hline & & 6 & 4 & 120 & 171 & 146 & \\
\hline \multirow[t]{2}{*}{2} & \multirow[t]{2}{*}{2008} & 8 & 31 & 120 & 32 & 76 & \multirow{2}{*}{92} \\
\hline & & 8 & 8 & 52 & 131 & 92 & \\
\hline \multirow[t]{2}{*}{3} & \multirow[t]{2}{*}{2009} & 3 & 17 & 152 & - & 76 & \multirow{2}{*}{76} \\
\hline & & 1 & 23 & - & 77 & 38 & \\
\hline \multirow[t]{2}{*}{4} & \multirow[t]{2}{*}{2010} & 3 & 12 & 96 & - & 48 & \multirow{2}{*}{88} \\
\hline & & 10 & 30 & 80 & 96 & 88 & \\
\hline \multirow[t]{2}{*}{5} & \multirow[t]{2}{*}{2011} & 10 & 27 & 97 & 55 & 76 & \multirow{2}{*}{76} \\
\hline & & 4 & 24 & - & 83 & 41 & \\
\hline \multirow[t]{2}{*}{6} & \multirow[t]{2}{*}{2012} & 4 & 5 & 138 & 64 & 101 & \multirow{2}{*}{101} \\
\hline & & 10 & 16 & - & 118 & 59 & \\
\hline \multirow[t]{2}{*}{7} & \multirow[t]{2}{*}{2013} & 8 & 6 & 85 & - & 42 & \multirow{2}{*}{56} \\
\hline & & 4 & 14 & 27 & 85 & 56 & \\
\hline \multirow[t]{2}{*}{8} & \multirow[t]{2}{*}{2014} & 6 & 15 & 140 & - & 70 & \multirow{2}{*}{76} \\
\hline & & 6 & 14 & - & 153 & 76 & \\
\hline \multirow[t]{2}{*}{9} & \multirow[t]{2}{*}{2015} & 6 & 7 & 97 & - & 49 & \multirow{2}{*}{55} \\
\hline & & 1 & 31 & - & 109 & 55 & \\
\hline \multirow[t]{2}{*}{10} & \multirow[t]{2}{*}{2016} & 11 & 16 & 113 & - & 56 & \multirow{2}{*}{61} \\
\hline & & 3 & 29 & 5 & 117 & 61 & \\
\hline
\end{tabular}

Sumber: Hasil Perhitungan, 2017 


\section{Perhitungan Curah Hujan Rancang- an}

Adapun rekapitulasi hasil perhitungan empat distribusi, yaitu: Distribusi Normal, Log Normal, Gumbel dan Log Pearson tipe III disajikan pada Tabel 2 di bawah ini:

Tabel 2. Rekapitulasi Hujan Rancangan

\begin{tabular}{|c|c|c|c|c|}
\hline $\operatorname{Tr}$ & $\begin{array}{c}\text { Normal } \\
(\mathrm{mm})\end{array}$ & $\begin{array}{c}\text { Log } \\
\text { Normal } \\
(\mathrm{mm})\end{array}$ & $\begin{array}{c}\text { Gumbel } \\
(\mathrm{mm})\end{array}$ & $\begin{array}{c}\text { Log Person } \\
\text { tipe III } \\
(\mathrm{mm})\end{array}$ \\
\hline \hline 2 & 82,59 & 79,22 & 79,972 & 76,472 \\
5 & 105,12 & 101,61 & 111,984 & 100,395 \\
10 & 116,92 & 115,75 & 133,178 & 117,883 \\
25 & 128,45 & 131,48 & 159,957 & 142,228 \\
50 & 137,57 & 145,41 & 179,824 & 162,393 \\
100 & 145,08 & 157,98 & 199,543 & 183,610 \\
200 & 151,78 & 170,13 & 219,191 & 206,560 \\
\hline
\end{tabular}

Sumber: Hasil Perhitungan, 2017

\section{Uji Kesesuaian Distribusi}

Uji kesesuaian distribusi dilakukan terhadap empat distribusi, yaitu: Distribusi
Normal, Log Normal, Gumbel dan Log Pearson tipe III.

- Uji Smirnov-Kolmogorov

Berdasarkan tabel kritis Uji SmirnovKolmogorov, untuk $\mathrm{n}=10$, dan $\alpha=5 \%$ diperoleh $\Delta \mathrm{cr}=0,41$ dan $\Delta$ maks $=0,009$. Karena $\Delta$ maks $<\Delta$ cr, maka dis-tribusi Log Pearson tipe III hipotesa diterima.

- Uji Chi-Square

Berdasarkan tabel harga Chi-Square

$\left(\mathrm{X}^{2}\right)$ untuk $\mathrm{d}^{\mathrm{k}}=1$ dan $\alpha=5 \%$ diperoleh $\mathrm{X}^{2}$ $=3,84$ dan $X_{\text {hitung }}^{2}=0,4$. Karena $X_{\text {hitung }}^{2}$ $\mathrm{X}_{\text {tabel, }}^{2}$ maka distrribusi Log Pearson tipe III yang diterima.

\section{Distribusi Hujan Jam-Jaman}

Analisa distribusi hujan jam-jaman dilakukan dengan menggunakan metode Mononobe, dengan durasi hujan selama 6 jam. Adapun grafik distribusi hujan disa-jikan pada Gambar 4 di bawah ini:

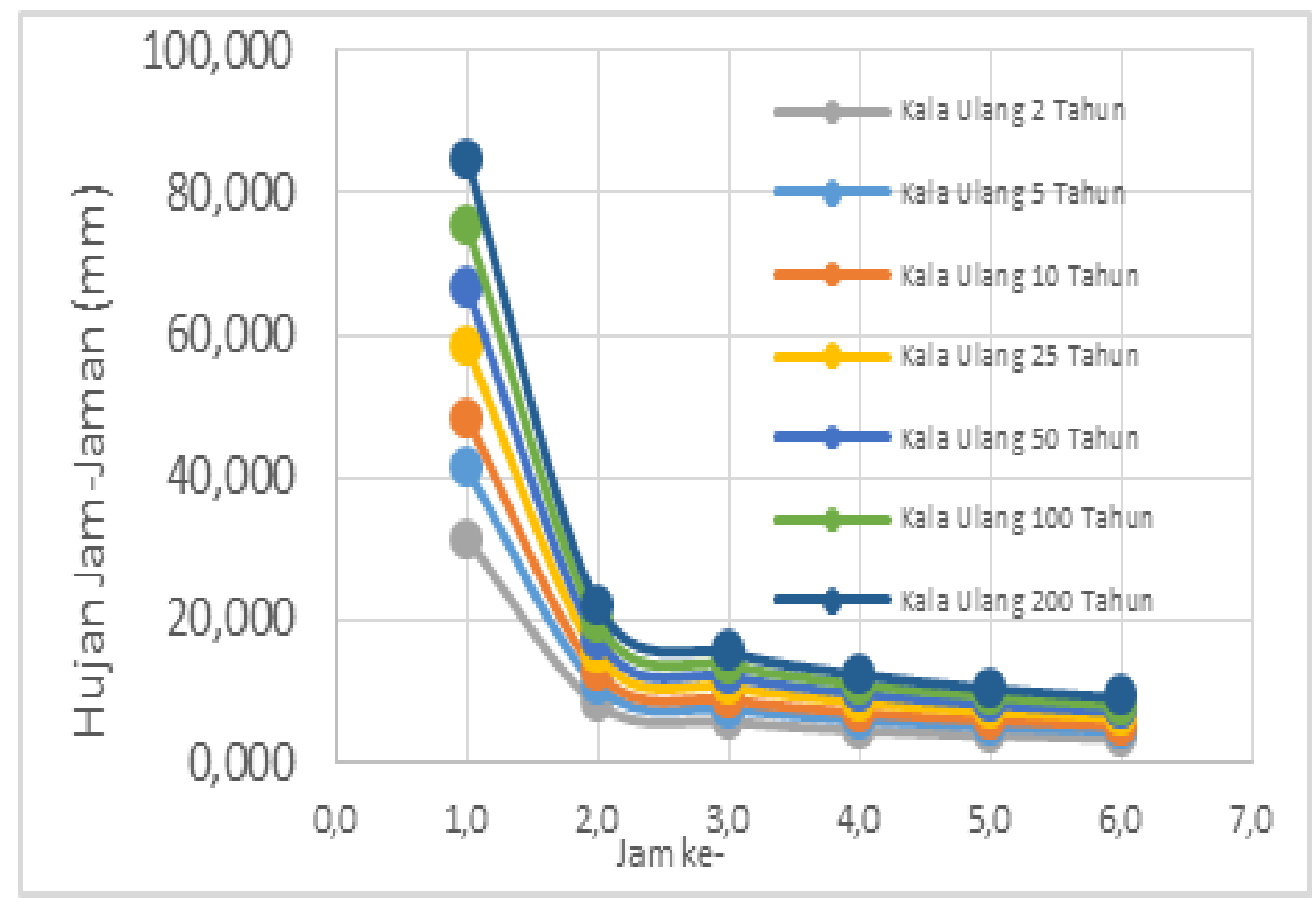

Gambar 4. Distribusi Hujan Netto Jam-Jaman

Evaluasi Saluran Sekunder (existing)

Evaluasi untuk mengetahui kondisi existing saluran mampu menampung/tidak jika sewaktu waktu terjadi hujan. Adapun hasil perhitungan disajikan pada Tabel 3 di bawah ini: 
Tabel 3. Perhitungan kapasitas saluran

\begin{tabular}{|c|c|c|c|c|c|c|c|c|}
\hline \multirow[t]{2}{*}{ No } & \multirow[t]{2}{*}{ Saluran } & $\Sigma A$ & \multirow[t]{2}{*}{$\mathrm{C}$} & Intensitas Hujan & Q Hujan & $\begin{array}{l}\text { Q Eksisting } \\
\text { Sekunder }\end{array}$ & Q Total & \multirow[t]{2}{*}{ Kondisi } \\
\hline & & $\left(\mathrm{Km}^{2}\right)$ & & $(\mathrm{mm} / \mathrm{jam})$ & $\left(\mathrm{m}^{3} / \mathrm{dt}\right)$ & $\left(\mathrm{m}^{3} / \mathrm{dt}\right)$ & $\left(\mathrm{m}^{3} / \mathrm{dt}\right)$ & \\
\hline (1) & $(2)$ & (3) & $(4)$ & (5) & $(6)$ & $(7)$ & $(8)=(7-6)$ & (9) \\
\hline 1 & Saluran Sekunder Kanan 3 & 0,268 & 0,750 & 11,788 & 0,658 & 2,666 & 2,008 & Memadai \\
\hline 2 & Saluran Sekunder Kanan 4 & 0.274 & 0,750 & 12,907 & 0,737 & 2,891 & 2,153 & Memadai \\
\hline 3 & Saluran Sekunder Kanan 5 & 0.254 & 0.750 & 11.788 & 0.625 & 2,045 & 1,420 & Memadai \\
\hline 4 & Saluran Sekunder Kanan 6 & 0.239 & 0,750 & 12.907 & 0.644 & 2,654 & 2,010 & Memadai \\
\hline 5 & Saluran Sekunder Kanan 7 & 0,362 & 0,750 & 11,788 & 0,889 & 2,555 & 1,666 & Memadai \\
\hline 6 & Saluran Sekunder Kanan 8 & 0,304 & 0,750 & 11,788 & 0,747 & 1,996 & 1,249 & Memadai \\
\hline 7 & Saluran Sekunder Kanan 9 & 0.363 & 0.750 & 12.907 & 0,978 & 2,665 & 1,687 & Memadai \\
\hline 8 & Saluran Sekunder Kanan 10 & 0.232 & 0,750 & 12,907 & 0.624 & 2,856 & 2,232 & Memadai \\
\hline 9 & Saluran Sekunder Kanan 11 & 0,141 & 0,750 & 18,535 & 0,547 & 2,233 & 1,687 & Memadai \\
\hline 10 & Sahuran Sekunder Kanan 12 & 0,089 & 0,750 & 18,535 & 0,343 & 1,953 & 1,610 & Memadai \\
\hline 1 & Saluran Sekunder Kiri 3 & 0.121 & 0.750 & 11,788 & 0.297 & 2,398 & 2,102 & Memadai \\
\hline 2 & Saluran Sekunder Kiri 4 & 0,147 & 0,750 & 12,907 & 0.395 & 2,858 & 2,463 & Memadai \\
\hline 3 & Saluran Sekunder Kiri 5 & 0,143 & 0,750 & 11,788 & 0,352 & 2,889 & 2,537 & Memadai \\
\hline 4 & Saluran Sekunder Kiri 6 & 0,147 & 0,750 & 11,788 & 0,362 & 2,798 & 2,437 & Memadai \\
\hline 5 & Saluran Sekunder Kiri 7 & 0.112 & 0,750 & 12.907 & 0.302 & 2,867 & 2,564 & Memadai \\
\hline 6 & Saluran Sekunder Kiri 8 & 0,125 & 0,750 & 11.788 & 0,308 & 2,867 & 2,558 & Memadai \\
\hline 7 & Saluran Sekunder Kiri 9 & 0,205 & 0,750 & 12,907 & 0,551 & 2,817 & 2,265 & Memadai \\
\hline 8 & Saluran Sekunder Kiri 10 & 0,166 & 0,750 & 12,907 & 0,446 & 3,276 & 2,830 & Memadai \\
\hline 9 & Saluran Sekunder Kiri 11 & 0.134 & 0.750 & 18,535 & 0.517 & 3,832 & 3,315 & Memadai \\
\hline \multirow[t]{2}{*}{10} & Saluran Sekunder Kiri 12 & 0,121 & 0,750 & 18,535 & 0,467 & 3,565 & 3,098 & Memadai \\
\hline & \multicolumn{4}{|c|}{ Jumlah total } & 10,790 & 54,680 & 43,890 & \\
\hline
\end{tabular}

Sumber: Hasil Perhitungan, 2017

Dari hasil perhitungan pada Tabel 3 debit hujan kala ulang 10 tahun keseluruh-an saluran sekunder yang ada mampu menampung debit hujan di saat tanaman padi sedang proses penyiangan.
Adapun hasil perhitungan genangan lahan akibat hujan disajikan pada Tabel 4 di bawah ini:

Tabel 4. Genangan lahan akibat hujan

\begin{tabular}{|c|l|c|r|r|c|}
\hline No. & \multicolumn{1}{|c|}{ Saluran } & $\begin{array}{c}\text { Debit hujan } \\
\left(\mathrm{m}^{3} / \mathrm{dt}\right)\end{array}$ & $\begin{array}{c}\text { Debit 6 jam } \\
\left(\mathrm{m}^{3}\right)\end{array}$ & \multicolumn{1}{c|}{ DPSal $\left(\mathrm{m}^{2}\right)$} & $\begin{array}{c}\text { Genangan } \\
(\mathrm{m})\end{array}$ \\
\hline 1 & \multicolumn{1}{|c|}{2} & \multicolumn{1}{c}{4} & \multicolumn{1}{c|}{5} & $6=4 / 5$ \\
\hline \hline 1 & Saluran Sekunder Kanan 3 & 0,66 & $14.221,08$ & \multicolumn{1}{c|}{$267.876,00$} & 0,053 \\
\hline 2 & Saluran Sekunder Kanan 4 & 0,74 & $15.928,91$ & $274.031,00$ & 0,058 \\
\hline 3 & Saluran Sekunder Kanan 5 & 0,62 & $13.493,62$ & $254.173,00$ & 0,053 \\
\hline 4 & Saluran Sekunder Kanan 6 & 0,64 & $13.908,72$ & $239.277,00$ & 0,058 \\
\hline 5 & Saluran Sekunder Kanan 7 & 0,89 & $19.207,56$ & $361.804,00$ & 0,053 \\
\hline 6 & Saluran Sekunder Kanan 8 & 0,75 & $16.138,63$ & $303.996,00$ & 0,053 \\
\hline 7 & Saluran Sekunder Kanan 9 & 0,98 & $21.127,77$ & $363.469,00$ & 0,058 \\
\hline 8 & Saluran Sekunder Kanan 10 & 0,62 & $13.471,66$ & $231.758,00$ & 0,058 \\
\hline 9 & Saluran Sekunder Kanan 11 & 0,55 & $11.807,35$ & $141.447,00$ & 0,083 \\
\hline 10 & Saluran Sekunder Kanan 12 & 0,34 & $7.419,05$ & $88.877,00$ & 0,083 \\
\hline 11 & Saluran Sekunder Kiri 3 & 0,30 & $6.404,84$ & $120.645,00$ & 0,053 \\
\hline 12 & Saluran Sekunder Kiri 4 & 0,40 & $8.532,80$ & $146.793,00$ & 0,058 \\
\hline 13 & Saluran Sekunder Kiri 5 & 0,35 & $7.598,37$ & $143.127,00$ & 0,053 \\
\hline 14 & Saluran Sekunder Kiri 6 & 0,36 & $7.812,00$ & $147.151,00$ & 0,053 \\
\hline 15 & Saluran Sekunder Kiri 7 & 0,30 & $6.528,72$ & $112.316,00$ & 0,058 \\
\hline 16 & Saluran Sekunder Kiri 8 & 0,31 & $6.658,02$ & $125.414,00$ & 0,053 \\
\hline 17 & Saluran Sekunder Kiri 9 & 0,55 & $11.905,22$ & $204.810,00$ & 0,058 \\
\hline 18 & Saluran Sekunder Kiri 10 & 0,45 & $9.635,55$ & $165.764,00$ & 0,058 \\
\hline 19 & Saluran Sekunder Kiri 11 & 0,52 & $11.164,84$ & $133.750,00$ & 0,083 \\
\hline 20 & Saluran Sekunder Kiri 12 & 0,47 & $10.096,19$ & $120.948,00$ & 0,083 \\
\hline & & & $233.064,92$ & $3.947 .431,00$ & 0,061 \\
\hline
\end{tabular}

Sumber: Hasil Perhitungan, 2017

Berdasarkan perhitungan genangan pada lahan akibat hujan diperoleh tinggi genangan rata-rata sebesar $0,061 \mathrm{~m}$.

\section{Pasang Surut}

Saluran primer D.I.R Pematang Limau bermuara pada DAS Seruyan yang merupakan 
intake dari wilayah studi. Berikut adalah grafik data pasang surut yang disajikan pada Gambar 5 di bawah ini.

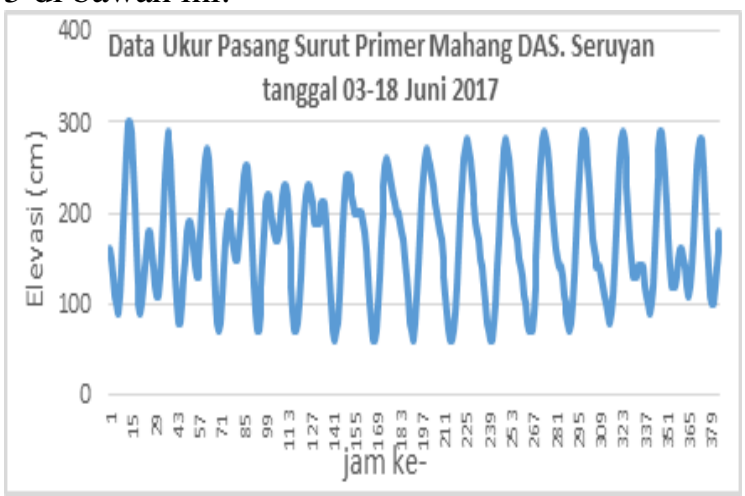

Gambar 5. Grafik data pasang surut
Konstanta pasang surut diperoleh dengan menggunakan Metode Least Square. Berdasarkan data ukur pasang surut selang satu jam selama 16 hari. Hasil perhitungan konstanta pasang surut disajikan pada Tabel 5 di bawah ini.

Tabel 5. Konstanta Pasang Surut

\begin{tabular}{|c|c|c|c|c|c|c|c|c|c|c|}
\hline & S0 & M2 & S2 & $\mathrm{N} 2$ & K1 & O1 & M4 & MS4 & K2 & $\mathrm{P} 1$ \\
\hline $\begin{array}{c}\mathrm{A} \\
(\mathrm{cm})\end{array}$ & - & 3,59 & 8,18 & 4,30 & 3,69 & 2,98 & 0,93 & 1,91 & 5,37 & 2,23 \\
\hline $\mathrm{g}^{0}$ & 170,09 & 52,07 & 8,18 & 14,60 & 3,75 & 62,56 & 31,57 & 18,58 & 0,08 & 0,22 \\
\hline
\end{tabular}

Sumber: Hasil Perhitungan, 2017

$$
\mathrm{F}=\frac{K 1+O 1}{M 2+S 2}=\frac{(3,69+2,98)}{(3,59+8,18)}=0,85
$$

Pasang surut campuran condong ke ganda (semi diurnal dominant).

Adapun data elevasi-elevasi penting pasang surut di wilayah studi disajikan pada Tabel 6 di bawah ini.

Tabel 6. Elevasi-Elevasi Penting Pasang Surut

\begin{tabular}{|c|l|c|c|}
\hline No & \multicolumn{1}{|c|}{ Keterangan } & $\begin{array}{c}\text { Pengamatan } \\
\text { Elevasi } \\
(\mathrm{cm})\end{array}$ & $\begin{array}{c}\text { Peramalan } \\
\text { Elevasi } \\
(\mathrm{cm})\end{array}$ \\
\hline 1. & $\begin{array}{l}\text { Highest High } \\
\text { Water Level } \\
\text { (HHWL) }\end{array}$ & 317,2 & 317,2 \\
\hline 2. & $\begin{array}{l}\text { Mean High Water } \\
\text { Spring (MHWS) }\end{array}$ & 264,0 & 264,0 \\
\hline 3. & $\begin{array}{l}\text { Mean High Water } \\
\text { Level (MHWL) }\end{array}$ & 231,3 & 231,3 \\
\hline 4. & $\begin{array}{l}\text { Mean Sea Level } \\
\text { (MSL) }\end{array}$ & 170,1 & 170,1 \\
\hline 5. & $\begin{array}{l}\text { Mean Low Water } \\
\text { Level (MLWL) }\end{array}$ & 109,6 & 109,6 \\
\hline 6. & $\begin{array}{l}\text { Mean Low Water } \\
\text { Spring (MLWS) }\end{array}$ & 73,0 & 73,0 \\
\hline 7. & $\begin{array}{l}\text { Lowest Low Water } \\
\text { Level (LLWL) }\end{array}$ & 17,1 & 17,5 \\
\hline
\end{tabular}

Sumber: Hasil Perhitungan, 2017

Adapun grafik prediksi pasang surut yang terjadi di wilayah studi disajikan pada Gambar 6.

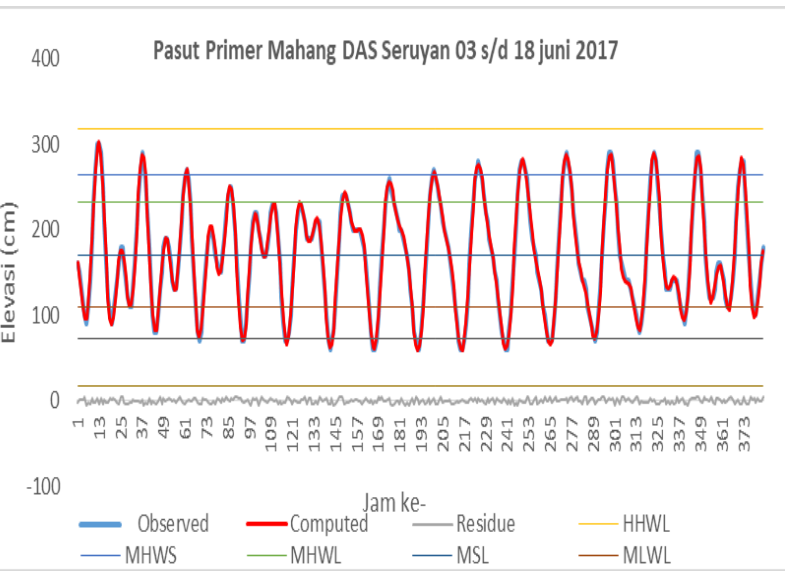

Gambar 6. Kurva pasang surut saluran primer DAS Seruyan

\section{Pengukuran Debit Pasang}

Pengukuran debit saluran primer D.I.R Pematang Limau dilakukan pada tanggal 14 Juni 2017 dengan menggunakan alat current meter.

\section{Analisa Profil Aliran}

Pada studi ini analisis hidrolika dila-kukan dengan menggunakan software program HECRAS 5.0.1.

\section{Penyusunan Model Hidrolika}

Langkah-langkah dalam penyelesaian analisis hidrolik dengan menggunakan 
program HEC-RAS 5.0.1 ini adalah sebagai berikut:

1. Membuat file new project

Langkah pertama pemodelan adalah membuat direktori file new project.

2. Peniruan geometri saluran

Langkah kedua adalah membuat peni-ruan geometri saluran primer dengan memasukan data-data geometri.

3. Peniruan hidrolika (syarat batas)

Langkah ketiga adalah memasukan datadata aliran yang diperlukan anali-

sis hidrolik aliran, dalam studi ini menggunakan aliran tidak permanen (unsteady flow).

4. Hitungan hidrolika

Langkah keempat dilakukan setelah semua data telah dimasukan baik berupa data geometri saluran, jenis aliran dan syarat batas dimasukan, perhi-tungan hidrolik unsteady flow dapat dilakukan.

5. Presentasi hasil hitungan

Setelah berhasil melakukan perhitung-an hidrolik dengan menjalankan pro-gram aliran tidak permanen (unsteady flow).

\section{Pembahasan}

Hasil analisa hidrolik aliran tidak permanen (unsteady flow). Berikut ini hasil proses empat simulasi, yaitu:

a). Simulasi pertama

Simulasi saluran primer tanpa pintu air.

Adapun profil aliran hasil simulasi disajikan pada Gambar 7, sedangkan data hasil simulasinya disajikan pada Tabel 7 .

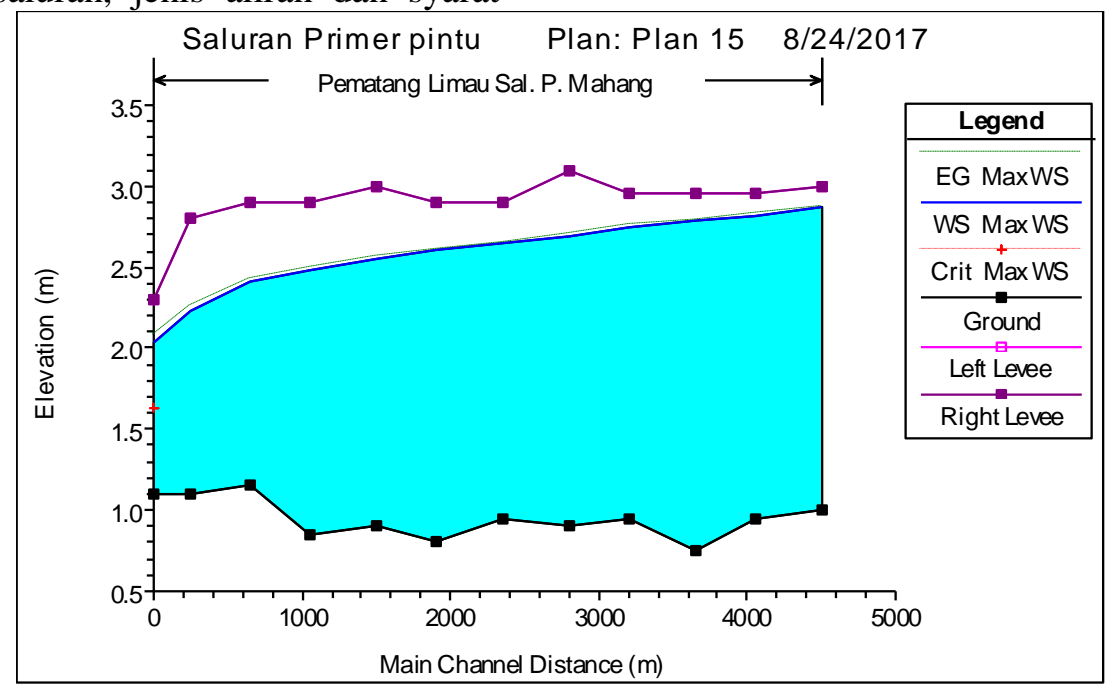

Gambar 7. Profil aliran long section saluran primer

Tabel 7. Data hasil simulasi long section

\begin{tabular}{|c|c|c|c|c|c|c|c|c|c|}
\hline $\begin{array}{c}\text { River } \\
\text { Sta }\end{array}$ & $\begin{array}{c}\text { Q Total } \\
\left(\mathrm{m}^{3} / \mathrm{s}\right)\end{array}$ & $\begin{array}{c}\text { Min Ch El } \\
(\mathrm{m})\end{array}$ & $\begin{array}{c}\text { W.S. } \\
\text { Elev }(\mathrm{m})\end{array}$ & $\begin{array}{c}\text { E.G. Elev } \\
(\mathrm{m})\end{array}$ & $\begin{array}{c}\text { E.G. Slope } \\
(\mathrm{m} / \mathrm{m})\end{array}$ & $\begin{array}{c}\text { Vel Chnl } \\
(\mathrm{m} / \mathrm{s})\end{array}$ & $\begin{array}{c}\text { Flow } \\
\text { Area } \\
\left(\mathrm{m}^{2}\right)\end{array}$ & $\begin{array}{c}\text { Top } \\
\text { Width } \\
(\mathrm{m})\end{array}$ & $\begin{array}{c}\text { Froude \# } \\
\text { Chl }\end{array}$ \\
\hline \hline 1 & 7.26 & 1 & 2.87 & 2.88 & 0.00012 & 0.47 & 15.54 & 10.95 & 0.13 \\
2 & 6.87 & 0.95 & 2.82 & 2.83 & 0.00009 & 0.42 & 16.31 & 10.95 & 0.11 \\
\hline 3 & 6.54 & 0.75 & 2.78 & 2.79 & 0.00007 & 0.38 & 17.23 & 10.98 & 0.10 \\
\hline 4 & 6.16 & 0.95 & 2.75 & 2.76 & 0.00008 & 0.35 & 17.41 & 15.01 & 0.10 \\
\hline 5 & 5.86 & 0.9 & 2.70 & 2.71 & 0.00015 & 0.50 & 11.82 & 9.55 & 0.14 \\
6 & 5.56 & 0.95 & 2.64 & 2.65 & 0.00011 & 0.40 & 13.77 & 11.78 & 0.12 \\
\hline 7 & 5.22 & 0.8 & 2.60 & 2.61 & 0.00007 & 0.34 & 15.23 & 11.89 & 0.10 \\
8 & 4.96 & 0.9 & 2.55 & 2.57 & 0.00015 & 0.47 & 10.47 & 8.68 & 0.14 \\
\hline 9 & 4.74 & 0.85 & 2.49 & 2.5 & 0.00016 & 0.46 & 10.2 & 9.42 & 0.14 \\
\hline 10 & 4.54 & 1.15 & 2.41 & 2.42 & 0.00022 & 0.51 & 8.89 & 9.39 & 0.17 \\
\hline 11 & 4.37 & 1.1 & 2.24 & 2.26 & 0.00056 & 0.73 & 5.97 & 7.15 & 0.26 \\
12 & 4.28 & 1.1 & 2.03 & 2.07 & 0.00100 & 0.84 & 5.07 & 7.95 & 0.34 \\
\hline
\end{tabular}

Sumber: Hasil Perhitungan, 2017 
b). Simulasi kedua

Simulasi saluran primer dengan pintu air (existing). Adapun profil aliran hasil simulasi disajikan pada Gambar 8, sedangkan data hasil simulasinya disajikan pada Tabel 8.

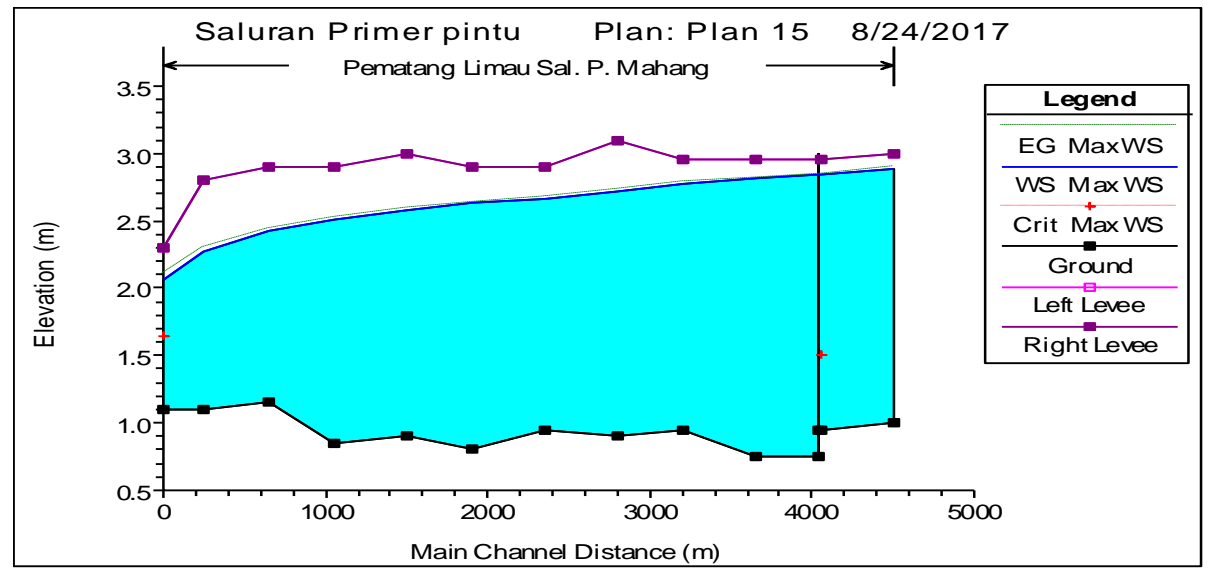

Gambar 8. Profil aliran long section saluran primer

Tabel 8. Data hasil simulasi long section

\begin{tabular}{|c|c|c|c|c|c|c|c|c|c|}
\hline $\begin{array}{c}\text { River } \\
\text { Sta }\end{array}$ & $\begin{array}{c}\text { Q Total } \\
\left(\mathrm{m}^{3} / \mathrm{s}\right)\end{array}$ & $\begin{array}{c}\text { Min Ch El } \\
(\mathrm{m})\end{array}$ & $\begin{array}{c}\text { W.S. } \\
\text { Elev }(\mathrm{m})\end{array}$ & $\begin{array}{c}\text { E.G. Elev } \\
(\mathrm{m})\end{array}$ & $\begin{array}{c}\text { E.G. Slope } \\
(\mathrm{m} / \mathrm{m})\end{array}$ & $\begin{array}{c}\text { Vel Chnl } \\
(\mathrm{m} / \mathrm{s})\end{array}$ & $\begin{array}{c}\text { Flow } \\
\text { Area } \\
\left(\mathrm{m}^{2}\right)\end{array}$ & $\begin{array}{c}\text { Top } \\
\text { Width } \\
(\mathrm{m})\end{array}$ & $\begin{array}{c}\text { Froude \# } \\
\text { Chl }\end{array}$ \\
\hline \hline 1 & 7.26 & 1 & 2.89 & 2.9 & 0.00011 & 0.46 & 15.75 & 10.98 & 0.12 \\
\hline 2 & 6.85 & 0.95 & 2.84 & 2.85 & 0.000084 & 0.41 & 16.57 & 10.98 & 0.11 \\
\hline 3 & 6.85 & 0.75 & 2.81 & 2.82 & 0.000087 & 0.39 & 17.59 & 13.2 & 0.11 \\
\hline 4 & 6.41 & 0.95 & 2.78 & 2.78 & 0.000083 & 0.36 & 17.82 & 15.28 & 0.11 \\
5 & 6.07 & 0.9 & 2.72 & 2.74 & 0.000156 & 0.50 & 12.07 & 9.61 & 0.14 \\
\hline 6 & 5.75 & 0.95 & 2.67 & 2.68 & 0.000108 & 0.41 & 14.07 & 11.84 & 0.12 \\
\hline 7 & 5.40 & 0.8 & 2.63 & 2.64 & 0.000069 & 0.35 & 15.53 & 11.95 & 0.1 \\
\hline 8 & 5.13 & 0.9 & 2.58 & 2.59 & 0.00015 & 0.48 & 10.67 & 8.73 & 0.14 \\
\hline 9 & 4.89 & 0.85 & 2.51 & 2.52 & 0.000158 & 0.47 & 10.42 & 9.47 & 0.14 \\
\hline 11 & 4.69 & 1.15 & 2.43 & 2.44 & 0.000222 & 0.51 & 9.11 & 9.44 & 0.17 \\
\hline 12 & 4.51 & 1.1 & 2.27 & 2.29 & 0.000537 & 0.73 & 6.18 & 7.21 & 0.25 \\
\hline
\end{tabular}

Sumber: Hasil Perhitungan, 2017

c). Simulasi ketiga

Membuat lebar pintu menjadi $1,5 \mathrm{~m}$ dari sebelumnya $1 \mathrm{~m}$. Adapun profil aliran hasil simulasi disajikan pada Gambar 9, sedangkan data hasil simulasinya disajikan pada Tabel 9.

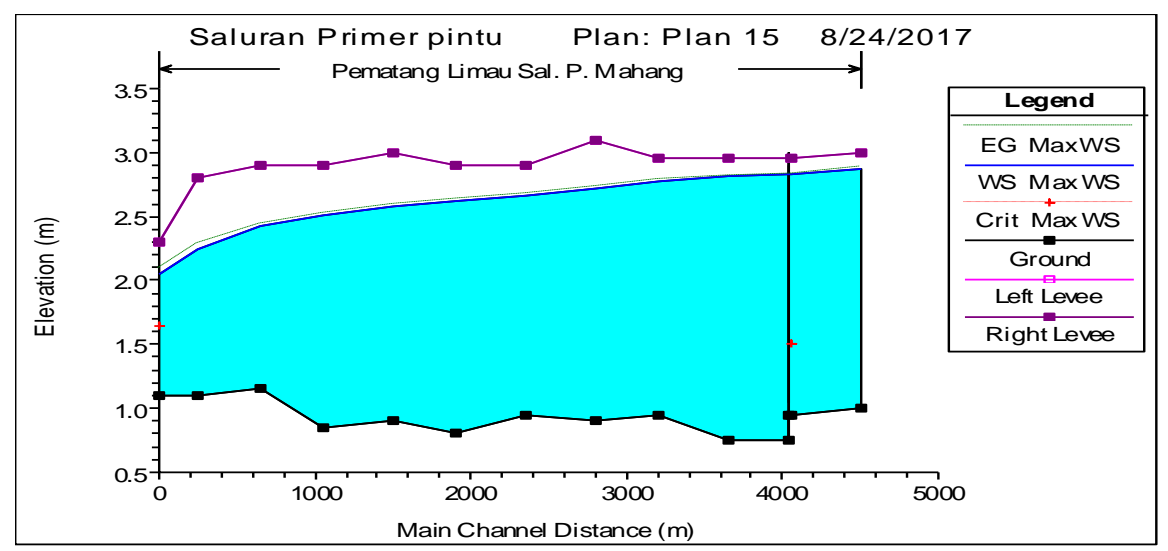

Gambar 9. Profil aliran long section saluran primer 
Tabel 9. Data hasil simulasi long section

\begin{tabular}{|c|c|c|c|c|c|c|c|c|c|}
\hline $\begin{array}{c}\text { River } \\
\text { Sta }\end{array}$ & $\begin{array}{c}\text { Q Total } \\
\left(\mathrm{m}^{3} / \mathrm{s}\right)\end{array}$ & $\begin{array}{c}\text { Min Ch El } \\
(\mathrm{m})\end{array}$ & $\begin{array}{c}\text { W.S. } \\
\text { Elev }(\mathrm{m})\end{array}$ & $\begin{array}{c}\text { E.G. Elev } \\
(\mathrm{m})\end{array}$ & $\begin{array}{c}\text { E.G. Slope } \\
(\mathrm{m} / \mathrm{m})\end{array}$ & $\begin{array}{c}\text { Vel Chnl } \\
(\mathrm{m} / \mathrm{s})\end{array}$ & $\begin{array}{c}\text { Flow } \\
\text { Area } \\
\left(\mathrm{m}^{2}\right)\end{array}$ & $\begin{array}{c}\text { Top } \\
\text { Width } \\
(\mathrm{m})\end{array}$ & $\begin{array}{c}\text { Froude \# } \\
\text { Chl }\end{array}$ \\
\hline \hline 1 & 7.26 & 1 & 2.87 & 2.88 & 0.00011 & 0.46 & 15.61 & 10.96 & 0.12 \\
\hline 2 & 6.86 & 0.95 & 2.83 & 2.83 & 0.00009 & 0.42 & 16.38 & 10.96 & 0.11 \\
\hline 3 & 6.86 & 0.75 & 2.81 & 2.82 & 0.00009 & 0.39 & 17.58 & 13.19 & 0.11 \\
\hline 4 & 6.42 & 0.95 & 2.78 & 2.78 & 0.00008 & 0.36 & 17.81 & 15.27 & 0.11 \\
\hline 5 & 6.08 & 0.9 & 2.72 & 2.74 & 0.00016 & 0.50 & 12.06 & 9.61 & 0.14 \\
6 & 5.77 & 0.95 & 2.67 & 2.67 & 0.00011 & 0.41 & 14.05 & 11.83 & 0.12 \\
\hline 7 & 5.41 & 0.8 & 2.63 & 2.63 & 0.00007 & 0.35 & 15.51 & 11.95 & 0.1 \\
\hline 8 & 5.14 & 0.9 & 2.58 & 2.59 & 0.00015 & 0.48 & 10.65 & 8.73 & 0.14 \\
\hline 9 & 4.91 & 0.85 & 2.51 & 2.52 & 0.00016 & 0.47 & 10.38 & 9.46 & 0.14 \\
10 & 4.70 & 1.15 & 2.42 & 2.44 & 0.00023 & 0.52 & 9.06 & 9.43 & 0.17 \\
\hline 11 & 4.53 & 1.1 & 2.25 & 2.28 & 0.00057 & 0.75 & 6.07 & 7.18 & 0.26 \\
\hline 12 & 4.44 & 1.1 & 2.05 & 2.09 & 0.00100 & 0.85 & 5.2 & 8.03 & 0.34 \\
\hline
\end{tabular}

Sumber: Hasil Perhitungan, 2017

d). Simulasi keempat

Merubah kekasaran manning semula 0.027 menjadi 0,018 dengan dimensi pintu air existing. Adapun profil aliran hasil simulasi disajikan pada Gambar 10, sedangkan data hasil simulasinya disajikan pada Tabel 10.

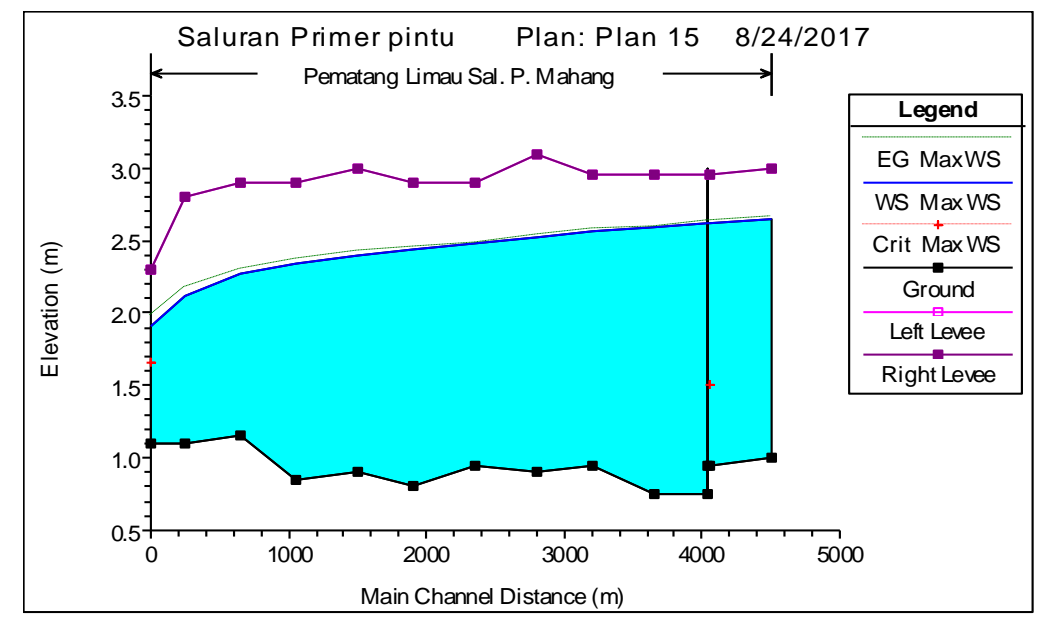

Gambar 10. Profil aliran long section saluran primer

Tabel 10. Data hasil simulasi long section

\begin{tabular}{|c|c|c|c|c|c|c|c|c|c|}
\hline $\begin{array}{c}\text { River } \\
\text { Sta }\end{array}$ & $\begin{array}{c}\text { Q Total } \\
\left(\mathrm{m}^{3} / \mathrm{s}\right)\end{array}$ & $\begin{array}{c}\text { Min Ch El } \\
(\mathrm{m})\end{array}$ & $\begin{array}{c}\text { W.S. } \\
\text { Elev }(\mathrm{m})\end{array}$ & $\begin{array}{c}\text { E.G. Elev } \\
(\mathrm{m})\end{array}$ & $\begin{array}{c}\text { E.G. Slope } \\
(\mathrm{m} / \mathrm{m})\end{array}$ & $\begin{array}{c}\text { Vel Chnl } \\
(\mathrm{m} / \mathrm{s})\end{array}$ & $\begin{array}{c}\text { Flow } \\
\text { Area } \\
\left(\mathrm{m}^{2}\right)\end{array}$ & $\begin{array}{c}\text { Top } \\
\text { Width } \\
(\mathrm{m})\end{array}$ & $\begin{array}{c}\text { Froude \# } \\
\text { Chl }\end{array}$ \\
\hline \hline 1 & 7.26 & 1.00 & 2.65 & 2.66 & 0.00008 & 0.55 & 13.19 & 10.58 & 0.16 \\
\hline 2 & 6.93 & 0.95 & 2.62 & 2.63 & 0.00006 & 0.49 & 14.20 & 10.63 & 0.13 \\
3 & 6.93 & 0.75 & 2.59 & 2.60 & 0.00005 & 0.46 & 15.09 & 10.67 & 0.12 \\
\hline 4 & 6.59 & 0.95 & 2.56 & 2.57 & 0.00005 & 0.44 & 15.02 & 12.55 & 0.13 \\
\hline 5 & 6.32 & 0.90 & 2.52 & 2.54 & 0.00012 & 0.62 & 10.14 & 9.15 & 0.19 \\
\hline 6 & 6.03 & 0.95 & 2.47 & 2.49 & 0.00009 & 0.51 & 11.83 & 11.45 & 0.16 \\
\hline 7 & 5.72 & 0.80 & 2.45 & 2.46 & 0.00005 & 0.43 & 13.39 & 11.51 & 0.13 \\
\hline 9 & 5.48 & 0.90 & 2.40 & 2.42 & 0.00012 & 0.60 & 9.17 & 8.34 & 0.18 \\
10 & 5.26 & 0.85 & 2.35 & 2.36 & 0.00013 & 0.59 & 8.91 & 9.11 & 0.19 \\
11 & 4.88 & 1.15 & 2.28 & 2.30 & 0.00019 & 0.66 & 7.69 & 9.13 & 0.23 \\
\hline 12 & 4.77 & 1.10 & 2.12 & 2.17 & 0.00047 & 0.94 & 5.17 & 6.92 & 0.35 \\
\hline
\end{tabular}

Sumber: Hasil Perhitungan, 2017 
Dari keempat proses simulasi model hidrolik tersebut di atas dibuat perbandingan elavasi yang disajikan pada Gambar 11. di bawah ini.

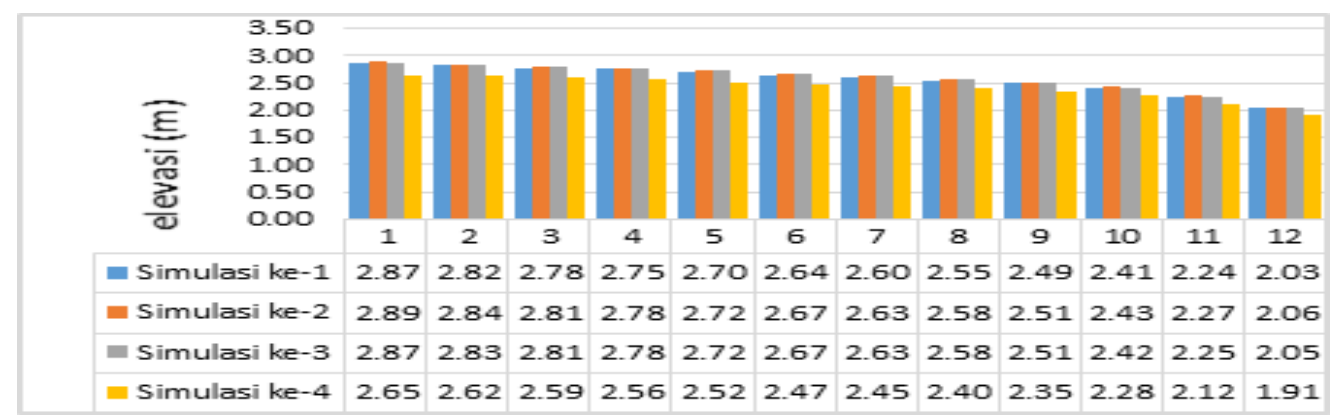

Gambar 11. Perbandingan elevasi long section

Berdasarkan Gambar 11 simulasi kedua menunjukan elevasi muka air tertinggi pada cross section 1-12.

\section{Evaluasi Simulasi (existing)}

Evaluasi dilakukan pada hasil simulasi kedua model hidrolik saluran primer D.I.R
Pematang Limau, yang dibagi menjadi dua parameter, yaitu:

Adapun grafik kedua parameter tersebut disajikan pada gambar 12 s/d 13 di ba-wah ini.

(1) Elevasi muka air profil memanjang (long section)

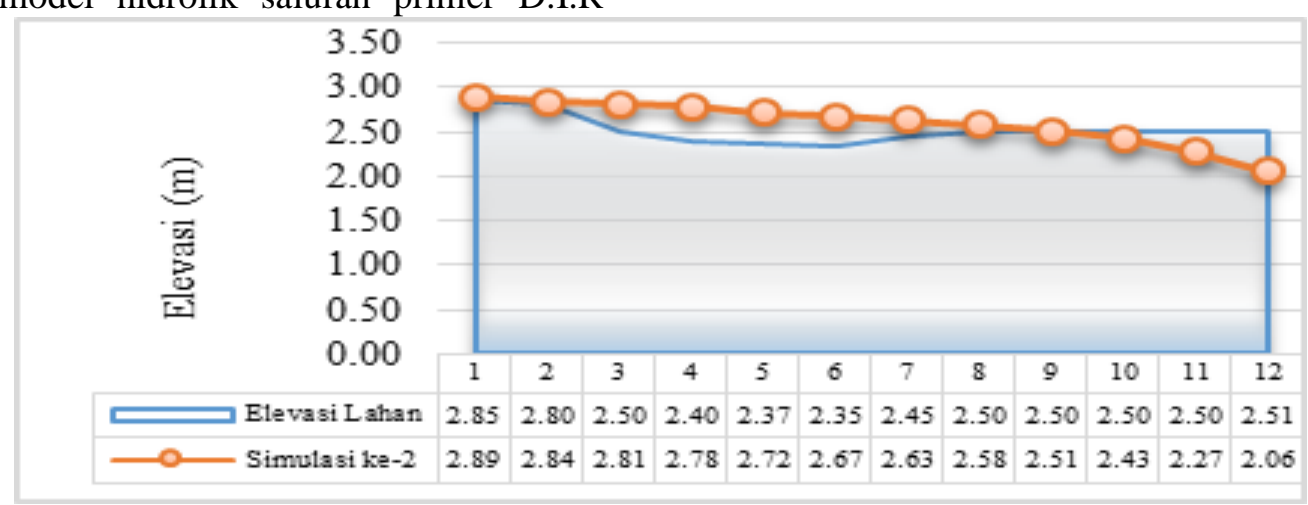

Gambar 12. Grafik perbandingan elevasi

(2) Kecepatan aliran (m/dt)

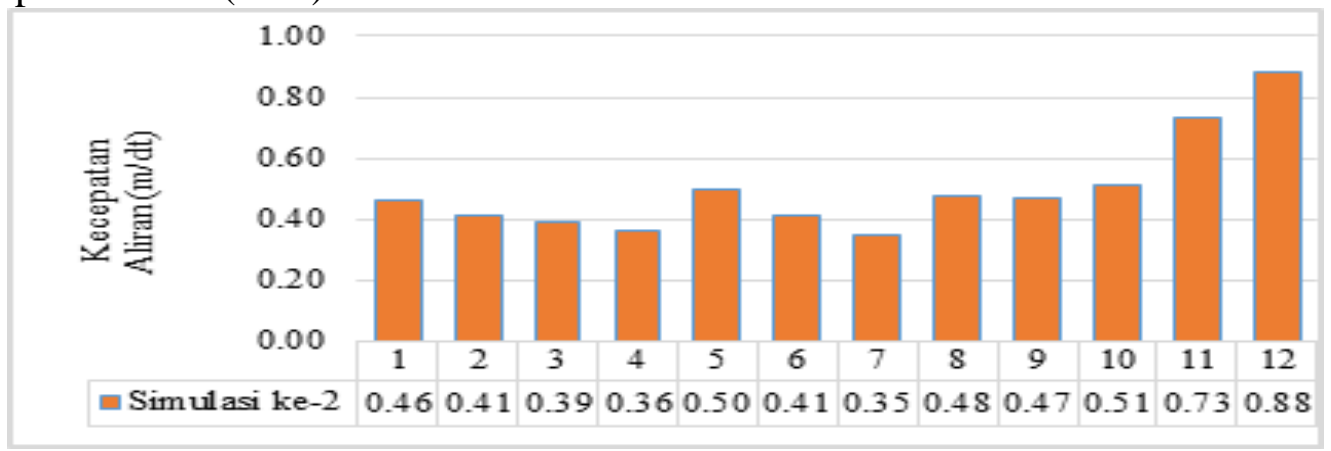

Gambar 13. Grafik kecepatan aliran

Berdasarkan gambar grafik kecepatan aliran pada cross section 5, 8, 9, 10, 11 adan 12 mengalami peningkatan, hal ini disebabkan pada cross section tersebut mengalami penyempitan, yaitu lebar atas (top width) saluran primer lebih kecil dibandingkan dengan cross section 1, 2, 3, 4, 6, dan 7. Secara keseluruhan lebar sal-uran sudah tidak sama akibat runtuh-nnya talud saluran dan penampang saluran sudah tidak berbentuk tarpesium. Lebar atas masing-masing saluran dapat dilihat pada Gambar 9 data hasil simulasi long section. 
Perhitungan Genangan Akibat Pasang dan Hujan

Perhitungan genangan pada lahan berdasarkan hasil simulasi kedua pada saluran

Tabel 11. Perhitungan genangan akibat pasang

\begin{tabular}{|c|c|c|c|c|c|c|}
\hline No & $\begin{array}{c}\text { Nama } \\
\text { Saluran }\end{array}$ & $\mathbf{A}^{\prime}(\mathbf{m} 2)$ & $\begin{array}{c}\text { Panjang } \\
(\mathbf{m})\end{array}$ & $\begin{array}{c}\text { Volume } \\
(\mathbf{m 3})\end{array}$ & $\begin{array}{c}\text { DPSal } \\
(\mathbf{m} 2)\end{array}$ & $\begin{array}{c}\text { Genangan } \\
(\mathbf{m})\end{array}$ \\
\hline$(1)$ & $(2)$ & $(3)$ & $(4)$ & $(5)=(4) \times(5)$ & $(6)$ & $(7)=(5) /(6)$ \\
\hline 1 & Sekunder 3 & 0,99 & & & & \\
\hline & & 1,49 & 450 & 671,25 & $388.521,0$ & 0,002 \\
\hline 2 & Sekunder 4 & 1,99 & & & & \\
\hline & & 2,14 & 400 & 856,67 & $420.824,0$ & 0,002 \\
\hline 3 & Sekunder 5 & 2,29 & & & & \\
\hline & & 2,39 & 450 & 1076,25 & $397.300,0$ & 0,003 \\
\hline 4 & Sekunder 6 & 2,49 & & & & \\
\hline & & 1,99 & 450 & 896,25 & $386.428,0$ & 0,002 \\
\hline 5 & Sekunder 7 & 1,49 & & & & \\
\hline & & 1,24 & 400 & 496,67 & $474.120,0$ & 0,001 \\
\hline 6 & Sekunder 8 & 0,99 & & & & \\
\hline & & 0,99 & 450 & 446,25 & $429.410,0$ & 0,001 \\
\hline 7 & Sekunder 9 & 0,99 & & & & \\
\hline & & 0,99 & 400 & 396,67 & $568.279,0$ & 0,001 \\
\hline 8 & Sekunder 10 & 0,99 & & & & \\
\hline & & 0,99 & 400 & 396,67 & $397.522,0$ & 0,001 \\
\hline 9 & Sekunder 11 & 0,99 & & & & \\
\hline & & 0,94 & 250 & 235,42 & $275.197,0$ & 0,001 \\
\hline 10 & Sekunder 12 & 0,89 & & & & \\
\hline & & 0,89 & 200 & 178,33 & $209.825,0$ & 0,001 \\
\hline & \multicolumn{2}{|l}{ Jumlah Volume } & & $5.650,42$ & $3.947 .426,0$ & 0,001 \\
\hline
\end{tabular}

Sumber: hasil perhitungan. 2017

Dari hasil tabulasi perhitungan pada Tabel 10 . Genangan akibat pasang, diperoleh tinggi genanagan rerata sebesar $0,001 \mathrm{~m}$ atau $1 \mathrm{~mm}$.

\section{Perhitungan Genangan Akibat Pasang dan} Hujan

Tabel 12. Genangan akibat pasang dan hujan

\begin{tabular}{|c|l|c|c|c|}
\hline \multirow{2}{*}{ No. } & \multirow{2}{*}{ Saluran } & \multicolumn{2}{|c|}{ Genangan $(\mathrm{m})$} & \multirow{2}{*}{$\begin{array}{c}\text { Total Genangan } \\
(\mathrm{m})\end{array}$} \\
\cline { 3 - 4 } & & Akibat Hujan & Akibat Pasang & $(4)=(3)+(4)$ \\
\hline$(1)$ & $(2)$ & $(3)$ & 0,002 & 0,055 \\
\hline \hline 1 & Sekunder 3 & 0,053 & 0,002 & 0,060 \\
\hline 2 & Sekunder 4 & 0,058 & 0,003 & 0,056 \\
\hline 3 & Sekunder 5 & 0,058 & 0,002 & 0,060 \\
\hline 4 & Sekunder 6 & 0,053 & 0,001 & 0,054 \\
\hline 5 & Sekunder 7 & 0,053 & 0,001 & 0,054 \\
\hline 6 & Sekunder 8 & 0,058 & 0,001 & 0,059 \\
\hline 7 & Sekunder 9 & 0,058 & 0,001 & 0,059 \\
\hline 8 & Sekunder 10 & 0,083 & 0,001 & 0,084 \\
\hline 9 & Sekunder 11 & 0,083 & 0,001 & 0,084 \\
\hline 10 & Sekunder 12 & 0,061 & 0,001 & 0,062 \\
\hline & Rata-rata & & & \\
\hline
\end{tabular}

Sumber: Hasil Perhitungan, 2017

Perhitungan ini berdasarkan hasil simulasi kedua bersamaan dengan terjadinya hujan diperoleh dari Tabel 11. Adapun hasil perhitungan disajikan pada pada tabel $12 \mathrm{di}$ bawah ini. primer, dengan asumsi saluran sekunder tersisi penuh. Adapun hasil perhitungan disajikan pada Tabel 11 di bawah ini. 
Dari hasil tabulasi perhitungan pada Tabel 12 . Genangan akibat pasang dan hujan, di-peroleh tinggi genanagan rerata sebesar $0,062 \mathrm{~m}$ atau $6,2 \mathrm{~cm}$.

\section{Rencana Penanganan}

Beradasarkan hasil dan evaluasi yang dilakukan, maka langkah-langkah penanganannya adalah sebagai berikut:

\section{Pola Operasi Pintu Air}

Pengaturan pola operasi buka/tutup pintu air, yaitu menutup pintu air ketika debit puncak pasang masuk, serta membuat rekomendasi setiap saluran sekunder dibuat pintu air dan ketika proses pasang berlangsung pintu air tersebut ditutup. Langkah ini dilakukan agar debit pasang yang masuk saluran primer tidak kembali ke sungai sehingga membuat elevasi muka air menjadi rata-rata dan elevasi muka air pada cross section 10-12 meningkat. Ada-pun hasil perhitungan disajikan pada Tabel 13, sedangkan grafik beda elevasi pada Gambar 18 di bawah ini.

Tabel 13. Perbandingan elevasi

\begin{tabular}{|c|c|c|c|c|c|}
\hline No. & Elevasi Lahan & Elevasi Muka Air Rata-rata & $\begin{array}{c}\text { Elevasi Muka Air } \\
\text { (simulasi kedua) }\end{array}$ & Beda elevasi & Beda elevasi \\
\hline$(1)$ & $(2)$ & $(3)$ & $(4)$ & $(5)=(4)-(2)$ & $(6)=(3)-(2)$ \\
\hline 1 & 2,850 & 2,599 & 2,890 & 0,040 & $-0,251$ \\
\hline 2 & 2,800 & 2,599 & 2,840 & 0,040 & $-0,201$ \\
\hline 3 & 2,500 & 2,599 & 2,810 & 0,310 & 0,099 \\
\hline 4 & 2,400 & 2,599 & 2,780 & 0,380 & 0,199 \\
\hline 5 & 2,370 & 2,599 & 2,720 & 0,350 & 0,229 \\
\hline 6 & 2,350 & 2,599 & 2,670 & 0,320 & 0,249 \\
\hline 7 & 2,450 & 2,599 & 2,630 & 0,180 & 0,149 \\
\hline 8 & 2,500 & 2,599 & 2,580 & 0,080 & 0,099 \\
\hline 9 & 2,500 & 2,599 & 2,510 & 0,010 & 0,099 \\
\hline 10 & 2,500 & 2,599 & 2,430 & $-0,070$ & 0,099 \\
\hline 11 & 2,500 & 2,599 & 2,270 & $-0,230$ & 0,099 \\
\hline 12 & 2,550 & 2,599 & 2,060 & $-0,490$ & 0,049 \\
\hline
\end{tabular}

Sumber: Hasil Perhitungan, 2017

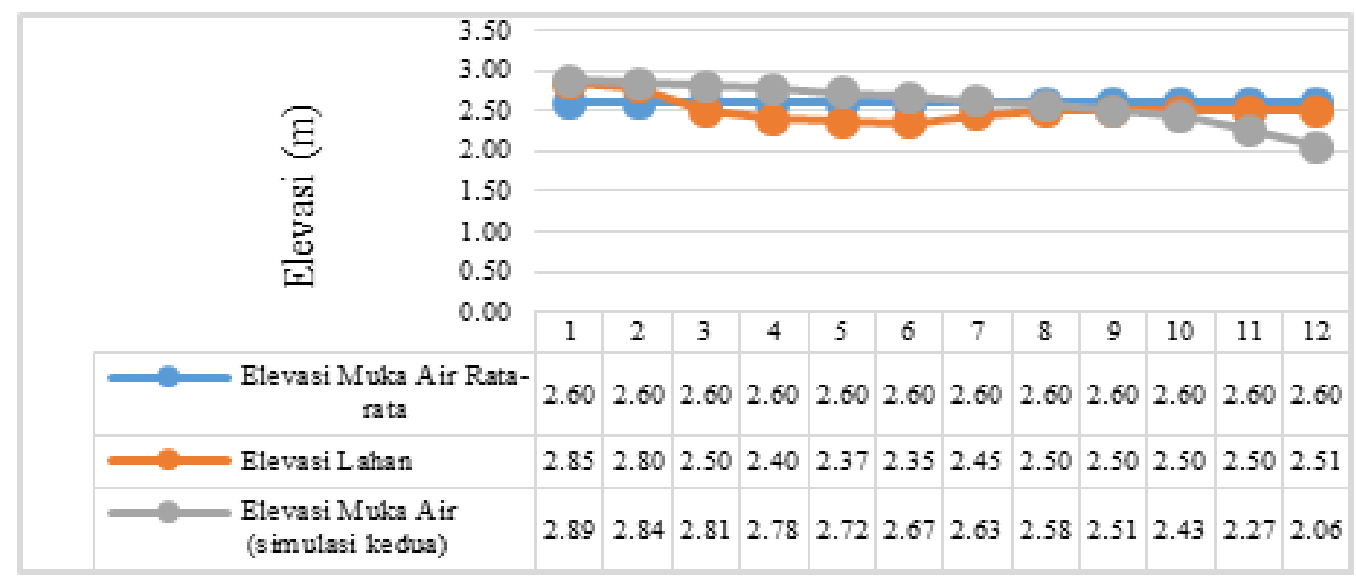

Gambar 14. Beda elevasi muka air

Berdasarkan hasil perhitungan pada Tabel 13. Perbandingan elevasi dan Gambar 14. Beda elevasi muka air. Kondisi ini menggambarkan muka air rerata mampu melampau elevasi lahan namun tidak maksimal, rata-rata tinggi genangan hanya $0,001 \mathrm{~m}$ atau $1 \mathrm{~mm}$.

\section{Pembagian Air Pasang Bergiliran}

Perhitungan genangan pada lahan berdasarkan hasil simulasi kedua, dengan asumsi saluran sekunder tersisi penuh. Adapun hasil perhitungan disajikan pada Tabel 14. 
Tabel 14. Perhitungan genangan (bergiliran)

\begin{tabular}{|c|c|c|c|c|c|c|c|}
\hline \multirow{2}{*}{ No } & \multirow{2}{*}{$\begin{array}{c}\text { Nama } \\
\text { Saluran }\end{array}$} & \multirow{2}{*}{$\begin{array}{c}\mathbf{A}^{\prime} \\
(\mathbf{m} 2)\end{array}$} & \multirow{2}{*}{$\begin{array}{c}\text { Pan- } \\
\text { jang } \\
\text { (m) }\end{array}$} & \multirow{2}{*}{$\begin{array}{c}\text { Volume } \\
\text { (m3) }\end{array}$} & \multirow{2}{*}{$\begin{array}{c}\text { DPSal } \\
(\mathbf{m} 2)\end{array}$} & \multicolumn{2}{|c|}{ Genangan (m) } \\
\hline & & & & & & $\begin{array}{c}\text { Bersa- } \\
\text { maan }\end{array}$ & Gilir-an \\
\hline$(1)$ & (2) & (3) & (4) & $(5)=(3) \times(4)$ & (6) & $(7)=(5 / 6)$ & $(8)$ \\
\hline \multirow[t]{2}{*}{1} & Sekunder 3 & 0,99 & & & & & \\
\hline & & 1,49 & 450 & 671,25 & $388.521,00$ & 0,002 & 0.01 \\
\hline \multirow[t]{2}{*}{2} & Sekunder 4 & 1,99 & & & & & \\
\hline & & 2,14 & 400 & 856,67 & $420.824,00$ & 0,002 & 0.01 \\
\hline \multirow[t]{2}{*}{3} & Sekunder 5 & 2,29 & & & & & \\
\hline & & 2,39 & 450 & 1076,25 & $397.300,00$ & 0,003 & 0.01 \\
\hline \multirow[t]{2}{*}{4} & Sekunder 6 & 2,49 & & & & & \\
\hline & & 1,99 & 450 & 896,25 & $386.428,00$ & 0,002 & 0.01 \\
\hline \multirow[t]{2}{*}{5} & Sekunder 7 & 1,49 & & & & & \\
\hline & & 1,24 & 400 & 496,67 & $474.120,00$ & 0,001 & 0.01 \\
\hline \multirow[t]{2}{*}{6} & Sekunder 8 & 0,99 & & & & & \\
\hline & & 0,99 & 450 & 446,25 & $429.410,00$ & 0,001 & 0.01 \\
\hline \multirow[t]{2}{*}{7} & Sekunder 9 & 0,99 & & & & & \\
\hline & & 0,99 & 400 & 396,67 & $568.279,00$ & 0,001 & 0.01 \\
\hline \multirow[t]{2}{*}{8} & Sekunder 10 & 0,99 & & & & & \\
\hline & & 0,99 & 400 & 396,67 & $397.522,00$ & 0,001 & 0.01 \\
\hline \multirow[t]{2}{*}{9} & Sekunder 11 & 0,99 & & & & & \\
\hline & & 0,94 & 250 & 235,42 & $275.197,00$ & 0,001 & 0.02 \\
\hline \multirow[t]{2}{*}{10} & Sekunder 12 & 0,89 & & & & & \\
\hline & & 0,89 & 200 & 178,33 & $209.825,00$ & 0,001 & 0.03 \\
\hline \multicolumn{4}{|c|}{ Jumlah Volume } & 5650,42 & $3947.426,0$ & 0,001 & 0.015 \\
\hline
\end{tabular}

Sumber: Hasil Perhitungan, 2017

\section{Perhitungan Irigasi Pompa}

Irigasi pompa merupakan alternatif terakhir ketika proses pemanfaatan air pasang tidak dapat memenuhi kebutuhan air pada lahan. (Kalsim, 2001: 19)

$q=\sum \frac{\mathrm{Axy}}{\mathrm{RxT}} \times \frac{1000}{36}=27,78 \times \sum \frac{394,74 \times 5}{6 \times 10}=913,83 \mathrm{~L} / \mathrm{dt}$ dengan:

$$
\begin{array}{ll}
\mathrm{A} & : 394,74 \mathrm{Ha} \\
\mathrm{y} & : 5,10,15 \text { dan } 20 \mathrm{~cm} \\
\mathrm{R} & : 6 \text { hari } \\
\mathrm{T} & : 10 \text { jam/hari }
\end{array}
$$

Perhitungan dengan kedalaman (y) $5 \mathrm{~cm}$ diperoleh q sebesar $913,83 \mathrm{~L} / \mathrm{dt}$ atau 0,91 m3/dt. Untuk memperoleh jumlah kebu-tuhan pompa dengan asumsi kapasitas pompa per unit sebesar 0,077 m3/dt.

$$
\text { maka }=\frac{0,91}{0,077}=11,92 \text { atau } 12 \text { unit }
$$

Tabel 15. Lama operasi pompa

\begin{tabular}{|c|c|c|}
\hline No. & $\begin{array}{c}\text { Kedalaman } \\
(\mathrm{cm})\end{array}$ & $\begin{array}{c}\text { Hari } \\
\text { Operasi }\end{array}$ \\
\hline 1 & 5 & 6 \\
2 & 10 & 12 \\
3 & 15 & 18 \\
4 & 20 & 24 \\
\hline
\end{tabular}

Sumber: Hasil Perhitungan, 2017

Dari hasil tabulasi perhitungan pada Tabel 15 lama operasi pompa berdasarkan kedalaman genangan yang diperlukan.

\section{Pengembangan D.I.R Pematang Limau}

Pengembangan dilakukan, yaitu: membuat pintu air di setiap saluran sekunder sebanyak 19 buah dan memperbaiki pintu air pada saluran primer dan sekunder masing-masing sebanyak 1 unit serta menyediakan pompa air sebanyak 12 unit. 


\section{KESIMPULAN DAN SARAN Kesimpulan}

1. Beradasarkan hasil evaluasi menunjukkan elevasi muka air saluran primer pada cross section 10-12 berada di bawah elevasi lahan, sehingga lahan yang berada disisi kanan/ kiri tidak tergenangi.

a. Dari keempat proses simulasi model hidrolik dilakukan pada saluran primer, simulasi kedua menunjukan elevasi muka air tertinggi pada cross section 1-12, maka dapat disim-pulkan pintu air existing yang ada masih ideal, dengan catatan perlu adanya perbaikan agar berfungsi sebagaimana mestinya.

b. Beradasarkan hasil perhitungan di saat kondisi hujan tidak terjadi pasang, saluran sekunder existing secara keseluruhan mampu menampung atau mendrainasi jika debit air hujan tersebut tidak dibutuhkan, sedangkan jika air hujan dibutuhkan dari hasil perhitungan diperoleh kedalaman genangan pada lahan sebesar 0,061 m.

c. Beradasarkan hasil simulasi di saat kondisi pasang bersamaan terjadinya hujan diperoleh kedalaman genangan pada lahan sebesar 0,062 $\mathrm{m}$.

2. Alternatif penanganan untuk menaikkan elevasi muka air pada saluran primer cross section 10-12, yaitu:

a. Dari hasil perhitungan rata-rata muka air terhadap elevasi di bagian hulu/ujung saluran diperoleh angka elevasi 2,60 $\mathrm{m}$ dan kedalaman genangan pada lahan sebesar 0,001 m. Untuk memaksimal genangan dilakukan sistem giliran terhadap masing-masing petak lahan diperoleh $0,015 \mathrm{~m}$.

b. Perlu dilakukan pengaturan pola operasi pintu air dengan menutup pintu air pada saluran primer ketika debit puncak air pasang yang masuk kesaluran dan menutup pintu-pintu air pada saluran sekunder agar proses pemerataan elevasi muka air dapat berjalan.

c. Alternatif terakhir untuk menaikkan tinggi genangan pada lahan antara 5-15 cm kondisi kemarau atau tidak terjadi hujan dalam jangka waktu lama perlu dilakukan pompanisasi. Jika tinggi genangan yang di inginkan $5 \mathrm{~cm}$ dengan lama operasi 10 jam/hari selama 6 hari, maka jumlah unit pompa yang di butuhkan berjumlah 12 unit.

3. Adapun rekomendasi alternatif penanganan, yaitu: memperbaiki pintu air pada saluran primer/sekunder, membuat pintu air untuk saluran sekunder yang belum memiliki pintu air sebanyak 19 buah dan menyediakan pompa air sebanyak 12 unit untuk mengatasi musim kering.

\section{Saran}

Berdasarkan hasil kajian pada studi ini, disarankan kepada pihak terkait, yaitu: Balai Wilayah Sungai Kalimantan II, antara lain:

1. Perlu adanya kajian lanjutan untuk mengetahui pengaruh hambatan air yang terjadi dari muara saluran primer pada DAS Seruyan hingga persimpangan atau titik nol pada studi ini.

2. Membuat pintu air disetiap saluran sekunder dengan tujuan untuk menahan debit air hujan keluar ataupun menahan debit air pasang ketika muka air di lahan sudah terpenuhi.

3. Mengatur pola operasi pintu air agar semua jaringan irigasi bisa di aliri dengan cara melakukan giliran bukaan pintu air.

\section{DAFTAR PUSTAKA}

Anonim. 2008. Kementerian Pekerjaan Umum Direktorat Rawa Pantai. Pengelolaan Rawa di Indonesia, Buku, 278 halaman.

Chow, Ven Te. 1997. Hidrolika Saluran Terbuka. Jakarta : Erlangga. 
http://istiarto.staff.ugm.ac.id/index.php/20 15/10/program-aplikasi-pasangsurut/ diakses tanggal 17-07-2017.

Istiarto. 2014. Modul Pelatihan Simulasi Aliran 1-Dimensi Dengan Bantuan Paket Program Hidrodinamika HEC-RAS Jenjang Lanjut: Gates. UGM. Yogyakarta.

Kalsim, Dedi K. 2001. Irigasi Pompa. Bagian Teknik Tanah dan Air, Fateta IPB.
Suhardjono. dkk. 2010. Reklamasi Daerah Rawa Untuk Pengembangan Persawahan. Citra Malang.

Suhardjono. 2015. Buku Ajar Drainase Perkotaan Jurusan Teknik Pengairan. Malang: Universitas Brawijaya.

Suripin. 2004.Sistem Drainase Perkotaan yang Berkelanjutan. Yogyakarta: Andi Offset. 